\title{
Diderma albo-columella (Myxomycetes), a new species in the Brazilian Atlantic Forest
}

Diderma albo-columella (Myxomycetes) uma nova espécie da Floresta Atlântica brasileira

\author{
Andrea Carla Caldas Bezerra ${ }^{1,3}$ \& Laise de Holanda Cavalcanti ${ }^{2}$
}

\begin{abstract}
A new species of Diderma (Physarales, Didymiaceae) was recorded in the Mata Estrela Private Nature Reserve, Rio Grande do Norte state. It is characterized by sessile sporangia, white globose columella, capillitium irradiating from the peridium, forming three layers, the middle part strongly calcareous, the outer layer cartilaginous and the inner layer membranous. A key to species of sessile sporangia Diderma with triple peridium is presented.

Key words: Didymiaceae, Neotropic, triple peridium.

Resumo

Uma nova espécie de Diderma (Physarales, Didymiaceae) foi registrada na Reserva Particular do Patrimônio Natural Mata Estrela, estado do Rio Grande do Norte, caracterizada por esporângio séssil, columela globosa, branca, capilício irradiando do perídio, formando três camadas, com a parte mediana fortemente calcárea, a parte externa cartilaginosa e a interna membranosa. Uma chave para espécies de Diderma com esporângios sésseis e perídio triplo é apresentada.

Palavras-chave: Didymiaceae, Neotrópico, perídio triplo.
\end{abstract}

\section{Introduction}

The genus Diderma was proposed in 1794 by Persoon, who emphasized the presence of a double peridium wall. The type species is $D$. globosum and in this genus there are 74 currently known species (Hernández-Crespo \& Lado 2005) distributed in different neotropic countries. Few species have triple peridium, such as $D$. lohogadense S.D. Patil, R.L. Mishra \& Ranade, D. nigrum Kowalski, D. petalloides Buyck, D. peyerimhoffii (Maire \& Pinoy) H. Neubert, Nowotny \& K. Baumann, D. trevelyanii (Grev.) Fr., D. maculatum Buyck, D. stellulum M.L. Farr, D. subasteroides M.L. Farr, and D. yucatanensis Estrada, Lado \& S.L. Stephenson. The last four were described for the Neotropics (Lado \&
Basanta 2008). Among the ten Diderma species found in Brazil, only D. stellulum has a triple peridium.

This paper describes a new species of Diderma with a triple peridium and sessile sporangia found during a survey of myxomycetes diversity in an Atlantic forest fragment situated in Rio Grande do Norte State, Northeast Brazil. A key to identify sessile Diderma species with triple peridium is also presented.

\section{Material and Methods}

Sporocarps were collected on an unidentified dead tree in the Mata Estrela Reserve, situated in Baia Formosa municipality, Rio Grande do Norte state $\left(06^{\circ} 22^{\prime} 10^{\prime \prime}-06^{\circ} 22^{\prime} 43^{\prime \prime}\right.$ 
S and 34 $58^{\circ} 29^{\prime \prime}-35^{\circ} 00$ '28" W, 1.833, 12 ha; $45 \mathrm{~m}$ alt.). Traditional herbarium methods were used in collecting and dehydrating specimens (Farr 1971).

The material was observed through the light microscope (LM) under oil immersion objective and with the scanning electron microscope (SEM). For ultramicroscopic studies, the material was Sporocarps prepared for scanning electron microscopy, were placed on double adhesive cellophane tape mounted on a specimen stub and sputtering with gold-palladium. The nomenclature followed in this paper is that of Martin \& Alexopoulos (1969) and Martin et al. (1983).

\section{Results and Discussion}

Diderma albo-columella A.C.C. Bezerra \& L.H. Cavalcanti, sp. nov. Typus: BRAZIL. RIO GRANDE DO NORTE: Baia Formosa Municipality, Mata Estrela Private Nature Reserve. Gameleira trail, 25. IV.2005, dead wood, A.C.C. Bezerra 45132 (holotype UFP!).

Fig. 1-2

Sporocarpi aggregati, sessili, $0.3-0.4 \mathrm{~mm}$ ex toto alt.; sporotheca discoidea, cremeis, peridio eius triplici, medio quidem coriaceo, calcareo; columella proeminentae, globosis, alba, calcarea; capillitio presis vel peridio interno; sporis 10.5-13.0 um diam., verrucosis.

Sporocarps sessile, densely aggregated, bright yellowish-brown, hemispheric-depressed to discoid, 0.4-0.8 $\times 0.3-0.5 \mathrm{~mm}$ diam., 0.3-0.4 mm alt., slightly umbilicated above. Hypothallus membranous, bright and continuous, dehiscence irregular. Peridium triple, the outer layer yellow, shining, cartilaginous, dehiscence irregular, the middle layer calcareous, white, thick, dehiscing simultaneously with the outer layer to which it closely adheres, the inner layer yellow, membranous. Collumela subglobose, $1 / 3-1 / 4$ of the sporotheca, white, calcareous. Capillitium abundant, with threads radiating from the inner layer of the peridium, violet brown, with hyaline extremities and short dilatations. Spore-mass dark brown. Spore dark to yellowish brown by transmitted light, globose to subglobose, $10.5-13.0 \mu \mathrm{m}$ diam.

The specific epithet is in reference to collumela color.

The new species differs from Diderma lohogadense. for not having circumscissile dehiscence and spinulose spores (Mishra \& Ranade 1979); from D. nigrum for not having brownish to black sporotheca and frequently lacking columella; from $D$. subasteroides, $D$. petalloides and D. stellulum for not having a stalk and the characteristic dehiscence, which gives the name of the species (Farr 1971; Buyck 1983); from D. peyerimhoffii for not having a clavate columella from which the dark threads of the capillitium irradiate, globose to fusiform expansions and spinulate spores; from D. maculatum (species described for Venezuela) for not having whitish peridium, with faint brown spots and the outer layer membranous, very fragile (Buyck 1984); and from D. yucatanensis, described for Ecuador (Lado et al. 2003), for not having stalked sporangia, capillitium threads attached to beige columella and spores less than $10 \mathrm{~mm}$ diam.

\section{Key to sessile Diderma species with triple peridium}

1. Subglobose on a narrow base, lower part persistent as a cup; dehiscence capillitium almost black, radiating from the columella, rarely anastomosed, with globose to fusiform expansions

D. peyerimhoffii

1'. Hemispheric-depressed, discoid, circular to elliptic in outline, seated on a broad base; dehiscence irregular; capillitium filiform, threads dark brown sometimes with hyaline extremities not radiating from the columella, anastomosed, without expansions .. 2

2. Sporangium whitish, with faint brown spots, spores 9.7-10 $\mu \mathrm{m}$ diam. D. maculatum

2'. Sporangium yellowish brown or dark brown to black, spores 10-14 $\mu \mathrm{m}$ diam. .. 3

3. Sporangium dark brown to black, 1-2 mm diam., dehiscence stellate; collumela often absent, or reduced to a calcareous, yellowish brown or sometimes white mound at the base of the sporotheca D. nigrum

3. Sporangium yellowish brown, $0.4-0.8 \mathrm{~mm}$ diam., dehiscence irregular; collumela present, globose to hemispherical, grayish white. D. albo-columela 

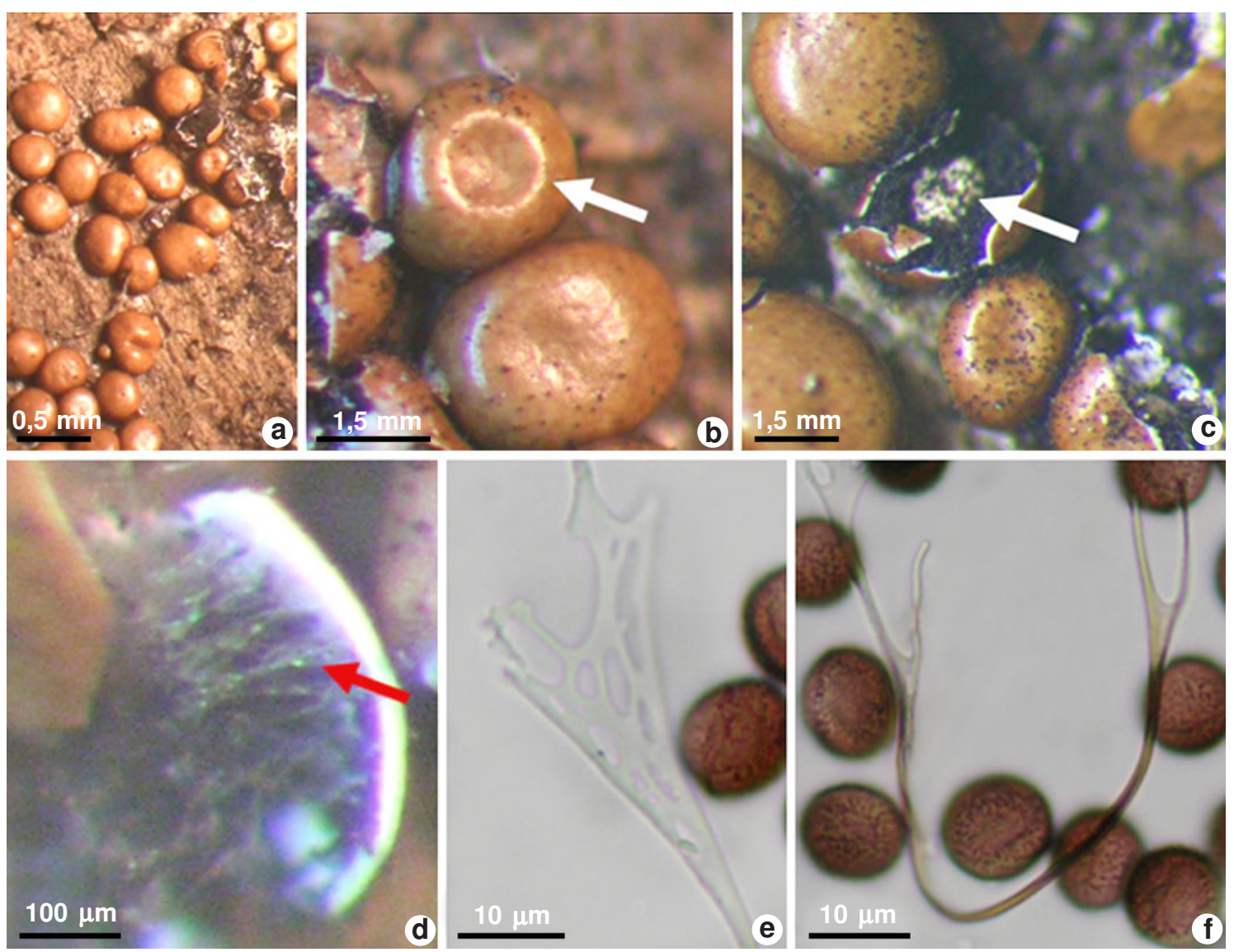

Figure 1 -Diderma albo-columella A.C.C. Bezerra \& L.H. Cavalcanti - a. sporocarps sessile, densely aggregated; b. sporocarp slightly umbilicated above; c. collumela subglobose; d. capillitium abundant, with threads radiating from the inner layer of the peridium; e-f. capillitium and spores (Bezerra 45132).
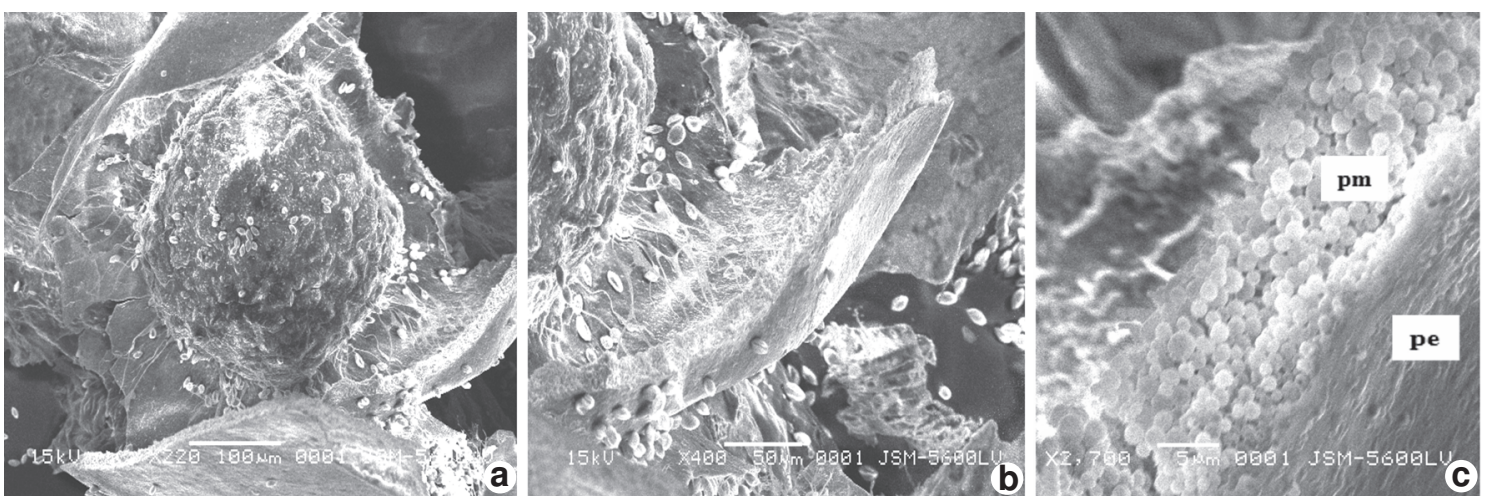

Figure 2 -Diderma albo-columella A.C.C. Bezerra \& L.H. Cavalcanti - a. sporangia open, exposing the columella; b. arrow shows the thick wall of the peridium and threads radiating from the inner layer; c. details of the triple wall: limestone; the outer layer (pe) and the middle layer calcareous (pm), thick, with the outer layer to which it closely adheres (Bezerra 45132). 


\section{Acknowledgments}

Aline E. Nascimento, of the Núcleo de Pesquisas em Ciências Ambientais, Universidade Católica de Pernambuco, Recife, PE, for the illustrations in MEV; PhD. Jose Carmine Dianese for the Latin diagnosis; Richard Boike for correcting the English; staff of the Laboratório de Myxomycetes (LABMIX) for field and laboratory assistance; board of the Mata Estrela Reserve for support during the collection period; the Conselho Nacional de Desenvolvimento Científico e Tecnológico (CNPq) for funding; the Botany Department of the Universidade Federal de Pernambuco for physical support.

\section{References}

Buyck, B. 1983. Diderma petaloides Buyck, a new Myxomycete from Rwanda. Bulletin du Jardin Botanique National de Belgique 53: 294.

Buyck, B. 1984. Diderma maculatum Buyck, a New Myxomycete from Venezuela. Bulletin du Jardin botanique national de Belgique/Bulletin van de National Plantentuin van België 54: 131-136.

Farr, M.L. 1971. Two undescribed Myxomycetes from Argentina. Mycologia 63: 634-639.

Hernández-Crespo, J.C \& Lado, C. 2005. An on-line nomenclatural information system of Eumycetozoa. Available in: <http://www.nomen.eumycetozoa.com>. Access on 18 August 2009.

Lado, C \& Basanta, D.W. 2008. A review of Neotropical Myxomycetes (1828-2008). Anales del Jardín Botánico de Madrid 65: 211-254.

Lado, C.; Estrada-Torres, A.; Stephenson, S.L.; de Basanta, D.W. \& Schnittler, M. 2003. Biodiversity assessment of myxomycetes from two tropical forest reserves in Mexico. Fungal Diversity 12: 67-110.

Martin, G.W. \& Alexopoulos, C.J. 1969. The Myxomycetes. University of Iowa Press, Iowa. 561p.

Martin, G.W.; Alexopoulos, C.J. \& Farr, M.L. 1983. The genera of Myxomycetes. University of Iowa Press, Iowa. 198p.

Mishra, R.L. \& Ranade, V.D. 1979. Myxomycetes of Maharashtra-II. The genus Diderma Pers. Patrika 14: 33-41. 